Editorial

\title{
Right-Wing Populist Party Organisation Across Europe: The Survival of the Mass-Party? Introduction to the Thematic Issue
}

\author{
Daniele Albertazzi ${ }^{1, *}$ and Stijn van Kessel ${ }^{2}$ \\ ${ }^{1}$ Department of Politics, University of Surrey, UK; E-Mail: d.albertazzi@surrey.ac.uk \\ ${ }^{2}$ School of Politics and International Relations, Queen Mary University of London, UK; E-Mail: s.vankessel@qmul.ac.uk \\ * Corresponding author
}

Submitted: 27 October 2021 | Published: 24 November 2021

\begin{abstract}
This thematic issue assesses the organisational forms of a broad range of right-wing populist parties (RWPPs) across Europe (12 in total). It interrogates received wisdom about the supposed leader-centeredness of such parties and investigates, in particular, the extent to which the mass party, as an organisational model, remains popular among RWPPs. This introduction presents the aims, research questions, and analytical framework of the issue and justifies its selection of cases. The resilience of the mass party model highlighted in many articles challenges the dominant trend that party organisation literature has identified: a unidirectional shift towards "catch-all," "electoral-professional," or "cartel" organisations.
\end{abstract}

\section{Keywords}

mass party; party membership; party organisation; populism; radical right

\section{Issue}

This editorial is part of the issue "Right-Wing Populist Party Organisation Across Europe: The Survival of the Mass-Party?" edited by Daniele Albertazzi (University of Surrey, UK) and Stijn van Kessel (Queen Mary University of London, UK).

(C) 2021 by the authors; licensee Cogitatio (Lisbon, Portugal). This editorial is licensed under a Creative Commons Attribution 4.0 International License (CC BY).

\section{Introduction}

Across Europe, traditionally dominant parties of the centre-right and centre-left have faced increasing electoral pressure from right-wing populist parties (RWPPs). These latter parties claim that they constitute the only alternative to political and other elites bent on imposing cultural change and uncontrolled migration on their populations. Whilst ample attention has gone out to RWPPs' ideological features, electoral performance, and broader impact (e.g., Mudde, 2007), the way they have organised themselves remains understudied. Although RWPPs are often still associated with centralised and "charismatic" leadership (e.g., Eatwell, 2018)-and some indeed adhere to this party model-many in fact aimed to establish complex and rooted organisations on the ground, and to foster an activist membership (Art, 2011; Heinisch \& Mazzoleni, 2016).

This observation has broader theoretical implications. It is often claimed that political parties are losing their traditional function of bridging the gap between citizens and the political elites. Whereas the first half of the 20th century saw the rise of parties that socialised citizens to politics, it is now widely assumed that the era of these so-called "mass parties" is over. Whilst the mass parties of yesteryear invested in recruiting activist members and building collective identities, the party organisation literature has since long identified trends towards alternative models, such as professional "catch-all" (Kirchheimer, 1966), "electoral-professional" (Panebianco, 1988) or "cartel" (Katz \& Mair, 1995) organisations. What these models have in common is a more diffuse ideological message and a weakening reliance on grassroots members. Our starting assumption is that RWPPs tend to conceive the relationship between citizens and party elites differently from most of their competitors: Their populist message challenges "the political elites" precisely for disengaging with ordinary citizens. This, we argue, provides them with an incentive to invest in an organisational model that relies on 
societal rootedness and the active shaping of members' political identities: the mass party model. In our thematic issue, we seek to empirically assess whether the mass party model is indeed still popular among RWPPs across Europe.

We identify the following key features of the mass party organisational model from the literature: (a) the drive to recruit a large activist membership as a way to reach out to the public through canvassing, campaigning and other means; (b) rootedness on the ground and the provision of a variety of activities to members; and (c) the preservation of "collective identities through ideology" (Panebianco, 1988, p. 268), by creating closed political communities of activists, promoting social integration among them and actively shaping their interpretations of political developments (Albertazzi, 2016). Following this interpretation, absolute membership numbers are not key to determining whether or not an organisation can be considered a "mass party." Just like the "cartel party" is defined by its relationship with the state (Katz \& Mair, 1995), the mass party should be defined via the relationship between its party elites and grassroots.

Ultimately, we seek to uncover the ideological aspects behind organisational choices (i.e., whether the mass party model appears to suit parties that explicitly claim to represent "the people"). We ask if, and to what extent, RWPPs tend to show mass party characteristics, and whether this also means grassroots members have meaningful influence over the parties' decisions. In order to increase representativeness in terms of case selection, the issue presents 12 studies of European RWPPs that vary in terms of socio-political context, age, electoral success, and governing experience. In the issue's concluding article, we consider whether general patterns can be observed regarding the organisation and centralisation of RWPPs, and whether meaningful variation can be identified.

In the remainder of this introductory article we present the research questions that guide the individual contributions, and thus form the analytical framework for this thematic issue. The final section introduces the parties selected for our research.

\section{Research Questions and Analytical Framework}

Contributors were asked to address the two main questions and related subquestions with reference to the current organisation of the party they covered. If important organisational developments had occurred over the years, authors were nevertheless invited to discuss those, too. The first question was geared at assessing whether the selected parties showed features of the mass party organisational model; the second focused on whether any mass party structures in fact allowed members to exercise meaningful influence over the party's internal procedures and decisions.

The questions were as follows:
1. To what extent, and how, do RWPPs invest in developing the "mass party" organisational model?

Systematic analysis was achieved by asking contributors to address four subquestions:

1.1. To what extent is the party characterised by a considerable degree of organisation?

1.2. How does the party try to attract members and activists?

1.3. What is the role of the internet and social media in party organisation and activism?

1.4. What are (probable) reasons for the decision to grow an active base of members and activists, or refraining from doing so?

As far as 1.1 is concerned, we follow Janda (1970, pp. 106-107, 1980, p. 98) in defining "degree of organisation" as "the complexity of regularized procedures for mobilizing and coordinating the efforts of party supporters in executing the party's strategy and tactics." Our contributors considered whether the party functions through a relatively complex set of party organs (e.g., executive committee, member assembly, etc.), or whether it is managed through a simple structure and by a relatively small group of people. Furthermore, we were interested in whether the parties developed a network of regional and local branches through which grassroots members are involved.

1.2 deals with the way the party reaches out to potential members (e.g., via street stalls, social media advertising, etc.), and whether it offers any particular incentives (material or otherwise) for joining. By answering 1.3, we take new forms of communication into account, assuming that these are imperative to understanding presentday party organisations. Here we ask how online means of communication (particularly social media) are used to attract support more generally. Finally, 1.4 deals with the motivations of the party leadership in adopting a particular type of organisation.

The second main question concerns the extent to which the selected parties allow members to exercise meaningful influence within their organisations:

2. To what extent do RWPPs remain centralised in terms of key decision-making areas such as ideological direction, campaigning, and internal procedures?

As alluded to above, we believe it is important to make a distinction between the complexity of a party organisation, on the one hand, and internal democracy, on the other. The two do not necessarily go together, as could be observed in the mass parties of the 20th century, in which party elites were ultimately in charge (Duverger, 1951; Michels, 1962). We therefore asked contributors to reflect on formal decision-making rules, but also on the actual informal powers leaders 
exercise within organisations, by answering two interrelated subquestions:

2.1. To what extent is decision-making power concentrated in the hands of the leader or a small circle of party elites?

2.2. To what extent, and in which ways, do RWPPs facilitate internal democracy?

2.1 relates to the "centralisation" of the party; following Janda (1980, p. 108), "a centralized party is one which features the concentration of effective decision-making authority in the national party organs, with a premium placed on a smaller number of individuals participating in the decision." Related to this, 2.2 focuses specifically on the extent to which ordinary party members have a say (via party bodies) in important decisions, pertaining to leadership and candidate selection, policy formulation, and more.

\section{Selected Right-Wing Populist Parties}

The parties we selected for our collaborative project all espouse populist discourses and culturally conservative positions. There exist a variety of labels for such parties, including Mudde's (2007) "populist radical right." Most of our cases fall into this category, given that their appeal is based on a combination of nativism, authoritarianism, and populism. Yet, given that we sought to include cases in Central and Eastern Europe which range more widely between centrism and extremism (e.g., Stanley, 2017), we opted for a concept at a slightly higher level of abstraction: "right-wing populism." For the purpose of the thematic issue, this is defined as an ideology "which pits a virtuous and homogeneous people against a set of elites and dangerous 'others' who are together depicted as depriving (or attempting to deprive) the sovereign people of their rights, values, prosperity, identity and voice" (Albertazzi \& McDonnell, 2015, p. 5).

Regarding our case selection, the thematic issue presents the first results of our comparative research project "Populist Parties in Action" which studies four long-established RWPPs in Western Europe: the Lega per Salvini Premier (LSP, League for Salvini Premier) in Italy, the Vlaams Belang (VB, Flemish Interest) in Belgium, the Schweizerische Volkspartei/Union Démocratique du Centre (SVP/UDC, Swiss People's Party) in Switzerland, and the Perussuomalaiset (PS, the Finns Party) in Finland. In this thematic issue we compare these established parties with relative RWPP newcomers in Western Europe, including the Alternative für Deutschland (AfD, Alternative for Germany), Forum voor Democratie (FvD, Forum for Democracy) in the Netherlands, and Vox in Spain. In addition, we broaden our comparative scope to post-communist Europe, by selecting parties with varying lifespans, organisational origins, electoral support and experience in office: the VMRO-Balgarsko Natsionalno Dvizhenie
(VMRO-BND, IMRO-Bulgarian National Movement), the Eesti Konservatiivne Rahvaerakond (EKRE, Estonian Conservative People's Party), Fidesz-Magyar Polgári Szövetség (FIDESZ, Fidesz-Hungarian Civic Alliance), Prawo i Sprawiedliwość (PiS, Law and Justice) in Poland, and the Slovenská Národná Strana (SNS, The Slovak National Party).

By showing how a fuller understanding of RWPPs' organisational models challenges conventional scholarly wisdom on party evolution, we ultimately aim to provide other researchers with a robust and nuanced conceptual framework for assessing differential party development in other contexts and party families, too.

\section{Acknowledgments}

The support of the Economic and Social Research Council (ESRC) is gratefully acknowledged (Grant Ref: ES/R011540/1). The authors would also like to thank the contributors of the thematic issue for their work and feedback, as well as Petra Guasti and Andrej Zaslove for their valuable comments on the project and individual case studies.

\section{Conflict of Interests}

The authors declare no conflict of interests.

\section{References}

Albertazzi, D. (2016). Going, going....not quite gone yet? "Bossi's Lega" and the survival of the mass party. Contemporary Italian Politics, 8(2), 1-16.

Albertazzi, D., \& McDonnell, A. (2015). Populists in power. Routledge.

Art, D. (2011). Inside the radical right: The development of anti-immigrant parties in Western Europe. Cambridge University Press.

Duverger, M. (1951). Les partis politiques [The political parties]. Armand Colin.

Eatwell, R. (2018). Charisma and the radical right. In J. Rydgren (Ed.), The Oxford handbook of the radical right (pp. 251-268). Oxford University Press.

Heinisch, R., \& Mazzoleni, O. (Eds.). (2016). Understanding populist party organisation. The radical right in Western Europe. Palgrave Macmillan.

Janda, K. (1970). A conceptual framework for the comparative analysis of political parties. Sage.

Janda, K. (1980). Political parties: A cross-national survey. Free Press.

Katz, R., \& Mair, P. (1995). Changing models of party organization and party democracy: The emergence of the cartel party. Party Politics, 1(1), 5-28.

Kirchheimer, O. (1966). The transformation of the Western European party systems. In J. LaPalombara \& M. Weiner (Eds.), Political parties and political development (pp. 177-200). Princeton University Press.

Michels, R. (1962). Political parties: A sociological study 
of the oligarchical tendencies of modern democracies.

The Free Press. (Original work published 1911)

Mudde, C. (2007). Populist radical right parties in Europe. Cambridge University Press.

Panebianco, A. (1988). Political parties: Organisation and power. Cambridge University Press.

Stanley, B. (2017). Populism in Central and Eastern Europe. In C. Rovira Kaltwasser, P. Taggart, P. Ochoa Espejo, \& P. Ostiguy (Eds.), The Oxford handbook of populism (pp. 140-160). Oxford University Press.

\section{About the Authors}

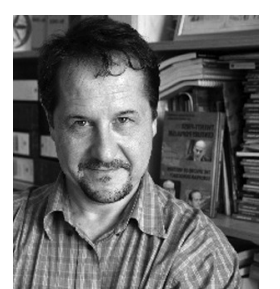

Daniele Albertazzi is professor of politics at the Department of Politics of the University of Surrey. The major strands of his work have been about populism in Western Europe, party organisation, Italian politics, Swiss politics, and the communication strategies and mass media use of political parties. Daniele's most recent books are Populism and New Patterns of Political Competition in Western Europe (Routledge, 2021), co-edited with Davide Vampa, and Populism in Europe-Lessons from Umberto Bossi's Northern League (Manchester University Press, 2021), co-written with Davide Vampa.

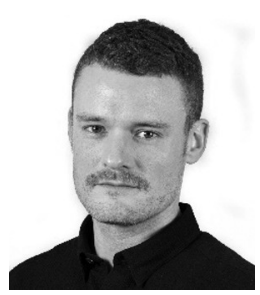

Stijn van Kessel is senior lecturer in European politics at Queen Mary University of London. His main research interests are populism and populist parties, as well as the politics of European integration. He is the author of Populist Parties in Europe: Agents of Discontent? (Palgrave, 2015) and of articles in journals including European Journal of Political Research, West European Politics, and Government \& Opposition. He is joint editor of the Routledge book series on Extremism \& Democracy. 